\title{
Human-Elephant Conflict in Sri Lanka: A Critical Review of Causal Explanations
}

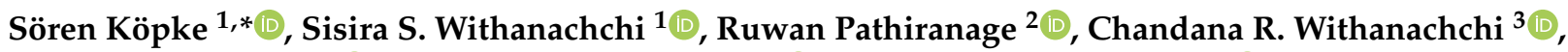

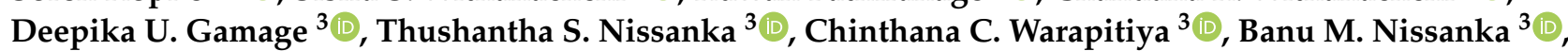

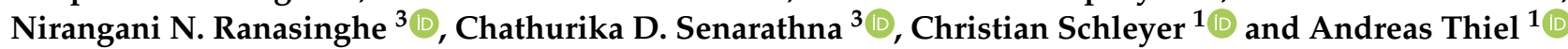 \\ 1 Faculty of Organic Agricultural Sciences, University of Kassel, 37213 Witzenhausen, Germany; \\ sisirawitha@uni-kassel.de (S.S.W.); schleyer@uni-kassel.de (C.S.); thiel@uni-kassel.de (A.T.) \\ 2 Eco-Collective Research Association, Colombo 00200, Sri Lanka; ruwan.yapahuwa@gmail.com \\ 3 Faculty of Social Sciences and Humanities, Rajarata University of Sri Lanka, Mihinthale 50300, Sri Lanka; \\ chandanawithanachchi@gmail.com (C.R.W.); deepikagamage56@yahoo.com (D.U.G.); \\ tsnissanka@gmail.com (T.S.N.); ccwara@gmail.com (C.C.W.); banulna@gmail.com (B.M.N.); \\ nirangani@ssh.rjt.ac.lk (N.N.R.); mail.chaturika@gmail.com (C.D.S.) \\ * Correspondence: soeren.koepke@web.de
}

Citation: Köpke, S.; Withanachchi, S.S.; Pathiranage, R.; Withanachchi, C.R.; Gamage, D.U.; Nissanka, T.S.; Warapitiya, C.C.; Nissanka, B.M.; Ranasinghe, N.N.; Senarathna, C.D.; et al. Human-Elephant Conflict in Sri Lanka: A Critical Review of Causal Explanations. Sustainability 2021, 13, 8625. https://doi.org/10.3390/ su13158625

Academic Editors: Brandon P. Anthony and Beatrice Frank

Received: 23 June 2021

Accepted: 29 July 2021

Published: 2 August 2021

Publisher's Note: MDPI stays neutral with regard to jurisdictional claims in published maps and institutional affiliations.

Copyright: (c) 2021 by the authors. Licensee MDPI, Basel, Switzerland. This article is an open access article distributed under the terms and conditions of the Creative Commons Attribution (CC BY) license (https:/ / creativecommons.org/licenses/by/ $4.0 /)$.

\begin{abstract}
Human-elephant conflict (HEC) is a severe and much-debated issue in Sri Lanka. An average of two hundred animals are intentionally killed, and seventy to eighty human casualties are counted each year. The Sri Lankan elephant (Elephas maximus maximus) is an endangered subspecies. The reported elephant mortality rates are high. On the other hand, human-elephant conflict also leads to hardship and trauma among rural populations. This research paper reviews causal explanations for HEC in Sri Lanka, tracing underlying narratives and connecting broader conservation theory and practical approaches. The paper discusses potential causes and contexts of HEC in Sri Lanka, including historical factors (i.e., colonial hunting and land-use changes), poaching, habitat loss due to population growth, crop-raiding behaviour, problem animals, and changes in agricultural production systems. The review concludes that socio-economic and cultural factors in HEC in Sri Lanka are poorly explained, and more research should focus on the underlying conditions of rural populations' vulnerability.
\end{abstract}

Keywords: human-elephant conflict; Sri Lanka; Asian elephant conservation; conservation social sciences

\section{Introduction}

Human-elephant conflict (HEC) is a severe and much-debated issue in Sri Lanka. HEC has become more intense over the last decade, compromising both the health of the local elephant population and the wellbeing of rural people, with on average more than two hundred animals killed and seventy to eighty human casualties annually [1-3].

The Sri Lankan elephant (Elephas maximus maximus) (see Figure 1) is listed as an endangered taxon according to the International Union for Conservation of Nature (IUCN).

The first elephant census in Sri Lanka, conducted by volunteers under the aegis of the Department of Wildlife Conservation (DWC) in 2011, led to a count of 5879 elephants in the wild [4]. (In September 2019, the DWC conducted its second islandwide elephant census, but results have not yet been published). There are also some tame elephants in the country, but as these generally do not breed in captivity, they are not of great interest from a conservation viewpoint.

The elephant, as a cultural symbol, is nearly omnipresent in Sri Lanka. In tourist shops, depictions of elephants can be found on anything from $t$-shirts to teacups. It is also the electoral symbol of Sri Lanka's oldest party, the United National Party. Throughout South Asia, the elephant is a sacred animal and an ancient symbol of royalty since 
pre-colonial armies used war elephants to demonstrate the king's power [5]. Elephants also feature prominently in Buddhist religious iconography adorning temples: a white elephant appeared in a dream to Queen Maya, Gautama Buddha's mother, before his birth, symbolising the advent of the prince and future sage [6]. Captive (temple) elephants are prominently used in the traditional esala peraheras, an important religious procession held in the Sri Lankan city of Kandy. There, tuskers carry the Tooth Casket, holding the most sacred artefact in Sri Lankan Buddhism. Overall, the importance of elephants to Sri Lankan culture is extremely high. Asian elephants are at risk of extinction [7]. The Sri Lankan elephant, by far the largest land animal in this Indian Ocean country, is both revered and feared. Its high symbolic and conservation value and the growing number of illegal killings are therefore clearly contradictory.

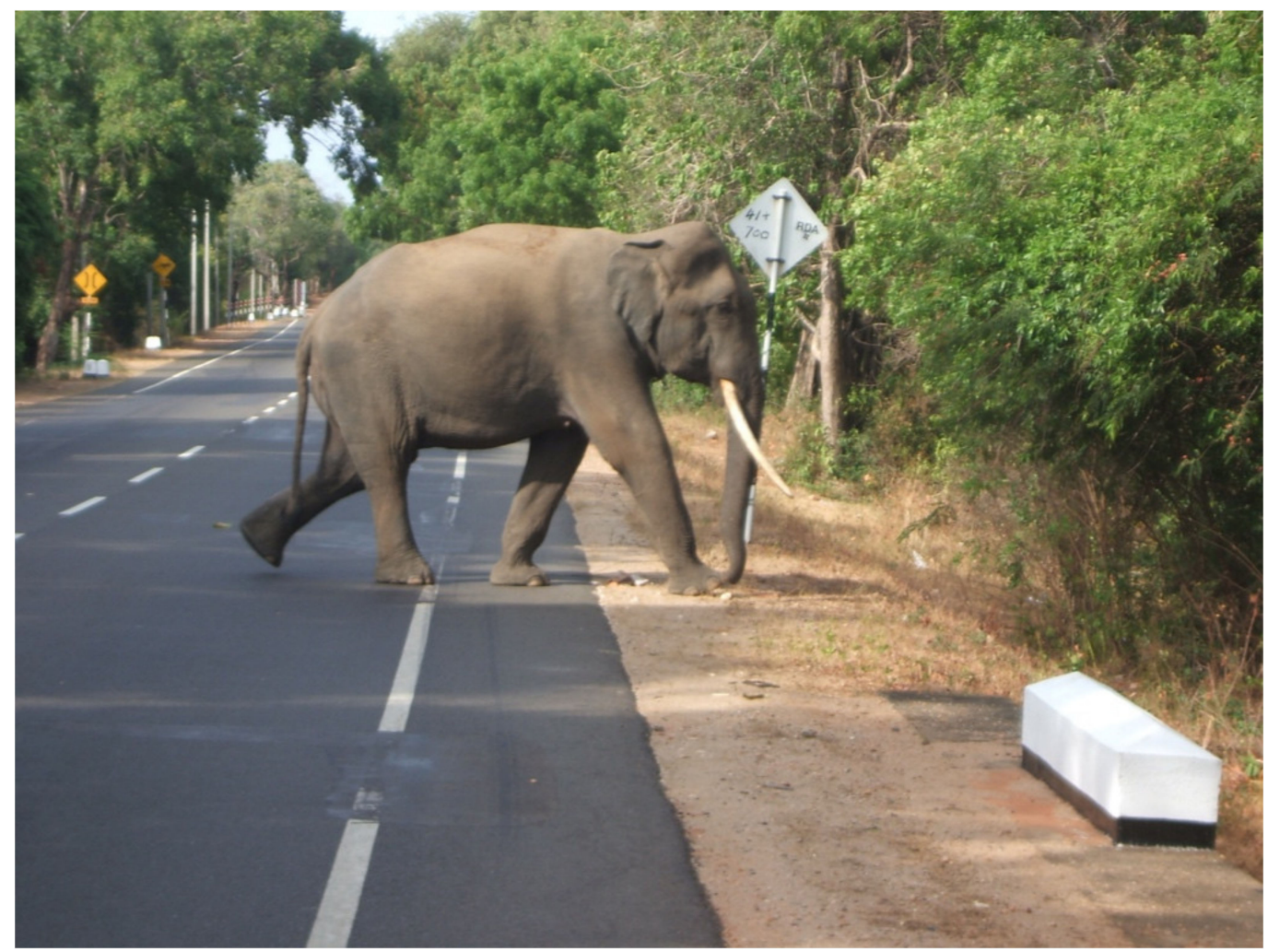

Figure 1. Sri Lankan elephant (Elephas maximus maximus), captured crossing a road. Photographer: Chandana R. Withanachchi.

HEC occurs in all Asian countries encompassing elephant ranges, even where wild elephant populations are minimal and fragmented, as in Yunnan, southern China, mostly due to elephant foraging behaviour [8]. In India, the absolute number of incidents of HEC, including human deaths and elephant deaths, is the highest in Asia. India also has the largest number of Asian elephants in a single country [8], followed by Sri Lanka [9], where over $70 \%$ of elephant ranges lie outside of protected areas (PA) [2], and therefore these are the spaces where human-elephant encounters are hostile and problematic. Due to this high intensity of human-elephant interactions outside of PA, the Sri Lankan case is particularly important.

\section{Theoretical Considerations and Methods}

The analysis of human-wildlife conflict (HWC) demands reflection on human-wildlife encounters' history, geography, ecology, and politics. Humans have engaged with wildlife for tens of thousands of years. Prehistoric hunter-gatherer societies had a tight relationship with wild animals, either as predators or prey, or both [10]. Prehistoric megafauna, specifically pachyderm species such as mammoths and mastodons, likely became extinct partly due to human "overkill" [11,12]. 
HWC is seen as an obstacle to biodiversity conservation, especially when it concerns charismatic, endangered species potentially threatening people's lives and livelihoods, such as tigers, wolves, elephants, or rhinos. These conflicts tend to have dramatic impacts on affected communities and individuals. At the same time, the common assumption that HWC is worsening is not supported by sound evidence for all species and regions [13].

Nyhus [14] alleges that human-wildlife encounters differ in frequency, the severity of impact, and positive or negative character. HWC would then refer to competition and conflict between humans and (most commonly) non-domesticated wild animals, based on the notion of a mutual threat and adverse impacts of one species on the other or its resource base. In a synthesis of the literature, Nyhus finds that HWC occurs with regard to a wide variety of animals: large terrestrial and amphibious species (carnivores/predators and herbivores and omnivores), reptiles, abundant agricultural pests, feral animals, and finally marine species.

It has been argued that "human-wildlife conflict" is principally a misnomer [15], as wildlife is essentially incapable of waging conflict in the sense human societies do. HWC is also viewed differently by humans who ascribe different values to wildlife, leading to conflict among those with differing perspectives. Hence, the term should be used carefully, with consideration of the underlying political and socio-economic contexts [16]. For the purpose of this review, we have decided to retain the terms HWC and HEC as these are widely used to describe the phenomenon.

Still, referring to encounters between human beings and wild animals as HWC is a matter of framing; HWC is an abstract concept competing with other conceptual approaches [17] such as resource- and land-use decisions, conservation governance, development, and economics. Baynham-Herd et al. [17] show in their metastudy of accounts of human-wildlife encounters how the framing of wildlife-related conflicts is linked to the intervention recommended by scientists. When problems were framed as "humanwildlife conflict", authors tended to recommend technical solutions, as opposed to the "illegal resource use" frame (i.e., poaching), which was associated with a call for enforcement. Following this insight, we hold the position that frames and narratives are good concepts to understand conservation policies with regard to human-wildlife interactions. Aukes et al. [18] mention that "frames" and "narratives" are often conflated in social science research. They define the former as reflecting the perspectives of individual actors, and the latter as referring to "a course of action with a beginning, a middle (often a complication) and an end (often a resolution) used by humans to make sense of experiences". A narrative might then be understood as the product of frames.

This paper aims to review potential explanations to HEC in Sri Lanka, trace underlying narratives, and connect different types of conservation intervention and mitigation strategies. The different dimensions of HEC in Sri Lanka and commonly cited causal relations are examined and evaluated. Seven narratives are identified that resurface in salient work on contemporary human-elephant conflict in Sri Lanka. Some contradict each other, while others are complementary (and not mutually exclusive) explanations of HEC in the country. This research is part of a collaborative project investigating the multiple factors, dynamics, and policies driving human-elephant conflict in Sri Lanka.

\section{Results}

\subsection{Colonial Elephant Hunting and Capture}

Historically, capture and sport hunting had a negative effect on the elephant population of Sri Lanka. The Kandyans, inhabitants of Sri Lanka's last independent kingdom (until 1817), had captured individual elephants and trained them either for ritual reasons and as personal assets, work animals, or as battle elephants. Historical sources indicate that from the Anuradhapura Kingdom (377 BCE-1017 CE), elephants were tamed and used for human purposes, warfare included $[19,20]$. Yet, the Portuguese, upholding a colonial presence in Sri Lanka since the early 16th century, were the first to capture elephants in mass operations to turn them into trade objects [21]. Later, during the Dutch colonial 
period (1640-1796), elephants, alongside cinnamon, comprised a major export product monopolised by the Dutch East India Company [22,23]. Before the British Empire took control of Sri Lanka (then called Ceylon) in 1815, there were allegedly 10,000-12,000 elephants on the island, yet these numbers appear to be exaggerated [24] (p. 38), [25] (p. 102).

Sport hunting was definitely among the reasons for the rapid decline of the elephant population in British Ceylon. During the 19th century, this activity was seen as a favourite pastime of British colonists [26] (p. 52). Lorimer and Whatmore [27] contextualise "The Hunt" as a performance of colonial power and an embodiment of masculinity. Hunting created a genetic legacy in elephants, as trophy hunters preferred to kill tuskers to the point of near extinction. However, Tennent [28] notices the scarcity of tuskers already in the mid-19th century:

"Had the motive which incites to the destruction of the elephant in Africa and India prevailed in Ceylon, and had the elephants there been provided with tusks, they would long since have been annihilated for the sake of their ivory."

Hunting also left its marks on the surviving elephant population: "The jungles of Ceylon would have been full of maimed, blind and suffering animals" [27] (p. 678).

As early as 1860, James Tennent [28] reported elephant numbers had been "considerably reduced", including due to the transformation of highland forests to coffee plantations, sport hunting, and the use of more lethal weapons by the Sinhalese:

"The opening of roads and the clearing of the mountain forests of Kandy for the cultivation of coffee, have forced the animals to retire to the low country; where again they have been followed by large parties of European sportsmen; and the Singhalese themselves, being more freely provided with arms than in former times, have assisted in swelling the annual slaughter."

It is noteworthy that Tennent already attributed the diminishing elephant population to a combination of factors. Tennent mentioned the impact of land-use change, which led to the displacement of elephants from the wet zone hill country. As a consequence of the emerging colonial conservation spirit in the British Empire [29], hunting would become less common as a practice in the second half of the 19th century [27]. From 1872 onward, sports hunting for elephants was increasingly regulated by law but only disappeared after independence in 1948 [30,31]. In contrast to some African countries, Sri Lanka does not currently licence or permit sport hunting for elephants.

\subsection{Poaching}

In the Asian elephant, only males possess tusks; however, in the Sri Lankan subspecies, the number of tuskers is below 10\% [32], most likely due to selective hunting [33] as explained above. Accordingly, poaching for ivory as an economic incentive to kill Sri Lankan elephants is now negligible. The extent to which Sri Lankan ivory was historically traded appears hard to discern [34]. For some decades, there was an artisanal ivory carving industry in the southern Sri Lankan town of Galle, a popular tourist destination [35].

Following Sri Lanka's involvement in the Convention on International Trade in Endangered Species of Wild Fauna and Flora (CITES) regulatory framework, the international ivory trade was banned, curbing raw ivory supply to the domestic ivory carving industry. At the same time, CITES was associated with a growing aversion of wealthier people to buying ivory products [36]. Santiapillai et al. [35] report the illegal poaching of tuskers in the north and east of the country during the Sri Lankan Civil War, supplying ivory carvers. Yet, after the end of the conflict in 2009, the illicit ivory trade and related poaching could not have been conducted any longer. Indeed, the few (but major) occurrences of poaching tuskers in recent years have attracted media attention and caused moral outrage among the Sri Lankan public. Overall, conservationists retain their call for a global ban on ivory commerce and emphasise the effectiveness of trade bans [37]. In 2016, Sri Lanka destroyed all stockpiled ivory in the country captured through the seizure of one single illegal shipment from East Africa; the destruction of 1.5 tons of ivory was accompanied 
by a Buddhist ceremony [38]. Recent insights highlight the importance of the commercial capturing of living individuals, especially baby elephants, for trade purposes [39].

\subsection{Habitat Loss and Human and Elephant Population Dynamics}

Habitat fragmentation and loss of habitat are seen as major causes for contemporary human-elephant conflict in Sri Lanka. Habitat fragmentation has earlier been described as resulting in a "pocketed herd phenomenon" [23] (p. 415), which means that groups are spatially isolated and lack sufficient genetic exchange among local populations. A new nationwide survey conducted in 2019 [2] shows that the Sri Lankan elephant metapopulation is "almost entirely contiguous", and no isolated herds appear to exist.

Elephant habitat loss is frequently associated with the growth of the human population in Sri Lanka: from 6.65 million in 1946, shortly before independence, to 20.36 million people in 2012 [40,41]. Jayewardene [42] (p. 30) sees a connection between human population growth and land transformation for human use. Bandara and Tisdell [43] (p. 3) claim "human population pressure on the Asian elephant ranges will increase with a corresponding increase in the demand for new land for human use". One of the most outspoken proponents of the approach linking population growth and interspecies conflict was the Sri Lankan conservation specialist and zoologist Charles Santiapillai [44] (p. 1):

"For a wide-ranging species like the elephant, this [loss of habitat available] means that the animal's flexibility to buffer the effects of local resource depletion by moving elsewhere [sic.] is lost. Such a situation has led to an escalation of conflicts between man and elephant in Sri Lanka."

The argument of incompatibility connected to carrying capacity and habitat loss is reiterated: "It is a truism that except at the lowest density, elephants and humans are fundamentally incompatible. This incompatibility increases rapidly as both elephant and human density increases", Santiapillai and Wijeyamohan [21] (p. 238) state and add: "It appears that Sri Lanka may have more elephants than it can sustain without much conflict with man" (p. 240).

Fernando [24] allows for a slightly different version of the habitat loss argument, pointing out that elephant conservation, on the one hand, and the persistent and wilful reduction of spaces habitable to elephants, on the other hand, are "fundamentally incompatible objectives", positioning development policies against conservation.

\subsection{Elephant Crop-Raiding Behaviour and Socio-Economic Grievances}

Crop foraging or crop-raiding by wild elephants constitutes a major grievance to affected farmers in the dry zone of Sri Lanka. Crop raiding mainly occurs in the evenings. During raids, elephants devour a wide variety of crops, mainly rice, banana, coconut, manioc, corn, and other fruits and vegetables [45] (pp. 24-26), [46].

Crop raids by wild elephants constitute an enormous economic loss for affected farmers. The megaherbivores can devour large amounts of food in a short time, and they also trample down field crops and gardens and have been known to damage buildings, walls, and fences. As a consequence, rural people perceive wild elephants as agricultural pests [43].

Usually, crop-raiding by wild elephants occurs seasonally when fruits ripen and are ready for harvesting. Farmers try to protect field crops against elephant pillages with varying success. Additionally, there have been many incidents recorded where elephants broke into houses to feed on stored harvest, causing financial losses, shock, and dismay for the occupants [47] (pp. 34-37), [3].

Compensation by the state appears to be minimal: Santiapillai et al. [45] (p. 23) found that $94 \%$ of affected farming households received no compensation payments. Additionally, farmers expressed low confidence in the compensation application process [48] (p. 31). The DWC reports that in 2017 it had paid 44,273,401 Sri Lankan Rupies (Rs) for 1350 applications of compensation in damages, Rs 45,500,000 in compensation for 105 applications for human deaths, and Rs 4,432,407 for 74 applications for injury damage, a total of around Rs 94,206,000 [49] (p. 26) in compensation for HEC-related losses; this sum was worth almost 
EUR 400,000 Euros at the time. This is more than double the amount in the previous year [50] (p. 25).

\subsection{Problem Animals}

Asian elephants have a sexually dimorphic social organisation; females live with juveniles in herds, while adult bulls mostly live alone or in small groups. Male elephants appear to be much more involved in HEC than female-majority herds and hence become targeted by lethal reactions more frequently. Crop raiding is also mainly associated either with solitary males or groups of males [24] (p. 40) [46,48]. A longitudinal study of the elephant population in Uda Walawe National Park indicates that victims of anthropogenic causes were predominantly male [51]. Sukumar [32] (p. 140) speculates that aggressive behaviour in (male) individuals might be learnt, indicating that this is a reaction against hostile treatment by humans, including shying the animals away from food sources. This stance is reiterated by Fernando [1] (p. 7), suggesting that HEC might be escalated by antagonistic treatment of elephants by humans.

Translocation, elephant drives, and so-called Elephant Holding Grounds (EHG) are prescribed mitigation mechanisms for dealing with problematic individuals. The translocation of single, almost exclusively male "problem elephants"-meaning capture and transportation to different sites-is a measure frequently used by the DWC as a conflict management mechanism [50,52]. A study by Fernando et al. [53] raises doubts on the effectiveness of translocation: elephants have high fidelity to their home ranges and were observedly attempting to return to their home ranges when translocated. In some cases, translocation even led to abnormal behaviour in elephants and, consequently, further incidences of HEC; hence, the measure can be highly counterproductive. What is more, a number of elephants died months after translocation.

Elephant drives denote the forced herding of elephants into different spaces, mainly into PA [50,52]. In 1978-1979, a large herding operation was undertaken, moving 160 elephants from the central-eastern Mahaweli basin to the Wilpattu National Park in the Northwest. Sukumar [32] (p. 24) describes the operation as successful, while Fernando et al. [54] evaluate it as a failure, as Wilpattu did not have an adequate carrying capacity for the translocated elephants.

In 2013, the DWC established an Elephant Holding Ground in Horowpothana, Anuradhapura District, North Central Province. The EHG was designed to hold 52 so-called problem elephants, exclusively males, from all over the country, which were translocated to the park. Electric fences surround the 1000-hectare area. According to the DWC's own evaluation report, in June 2019, only 9 elephants remained in the EHG; 12 had died and the remaining 31 could not be accounted for [55] (pp. 3-4).

"12 elephants had died and 05 [sic.] of them had died of malnutrition and lack of sufficient

foods. Further, another two elephants had died due to unattended translocation to the holding ground. It was observed that the health condition of the elephants retained at the holding ground remained at a poor level and no follow-up action had been taken on the health of these animals"

Criticisms notwithstanding, another EHG is being planned at Lunugamwehera, adjoining Ruhuna (Yala) National Park. Conservationists assert that in Horowpothana EHG, elephants probably starved to death and that the whole project was managed in an unscientific manner and lacked proper monitoring [56]. Others perceive the EHG as an "elephant prison" [57]. The neglect of elephants in the EHG is seen as an impediment to their survival in the area.

\subsection{Agricultural Modernisation and Failed Cohabitation}

There is evidence that agricultural production systems, and transformation thereof, could be linked to the high frequency of crop raids. In their study of a village in the dry zone of Sri Lanka, Anuradha et al. [58] collected oral histories of the village, which reveal significant land-use changes: abandoning traditional practices of chena (swidden) in favour 
of permanent cultivation of fields. The authors argue that chena, with its fallow periods of several years, facilitates the peaceful cohabitation of elephants and human beings, as the former find an appropriate food source in fallow fields. When more land is brought under seasonal or permanent crops, the opportunistic feeding behaviour of the elephants steers them towards cultivated areas. Moreover, in traditional village societies, chena was associated with cultivating crops outside of the food preference of animals such as elephants and wild boars, discouraging them from entering fields during cultivation.

In contemporary rural settings, the economic incentive to grow cash crops led to fundamental changes in cropping patterns on the household level, which coincide with the food preferences of elephants. Ranaweerage [59] describes a case from the Central Province where a ban on and subsequent abandonment of chena resulted in a rise of elephant foraging in newly established home gardens, increasing HEC in the area.

It has been observed that elephants prefer perennial water bodies without temporal human settlements, including abandoned tanks in the dry zone [60]. Tanks are humanmade reservoirs, relicts of Sri Lanka's irrigation-based "hydraulic civilisation" (ca. 200 BCE to 1200 CE); in this sense, the dry zone is deeply shaped by historical human activities. Additionally, elephants, as a keystone species, proactively maintain grassland landscapes through their feeding behaviour [61] (p. 36). Lorimer [62] argues that Sri Lankan dry zone landscapes are co-produced by humans and elephants, pointing towards the historical culture of cohabitation of humans and elephants. The failure of cohabitation would then be the consequence of modernised, intensified agricultural production systems.

\subsection{Conservation and Social Justice}

As of 2017, Sri Lanka had 101 PA, including 24 national parks [50] (pp. 72-74). These are under the management of the DWC, a state agency described by former director Sumith Pilapitiya as "understaffed" and subject to "political interference" [63], and this critique has also been aimed at PA in Sri Lanka, which play an essential role in elephant conservation.

Benadusi [64] discusses spatial politics in and around Yala (Ruhuna) National Park; Yala lies in the south of the country and is the country's most-visited national park. Yala (Ruhuna) is here conceptualised as a neoliberal project of commodifying nature, a global destination for ecotourism. Yet, the people living in surrounding villages do not profit adequately from the park, while they bear the burden of elephant intrusion into their homes and fields. Benadusi traces how the "neoliberal landscape" of Yala has adverse effects on the surrounding communities, including elephants foraging crops, causing destruction to property, and human deaths. In addition, farmers' access to the natural resources in and around the park are compromised by conservation practices.

Likewise, de Silva and Srinivasan [65], with empirical evidence from Viharamahadevipura, a park adjacent to Yala (Ruhuna), criticise rigid "fortress conservation" policies and "nature-society" dualisms. In their case study research area, almost all farmers report negative encounters with elephants; $54 \%$ of respondents estimate the loss from elephant crop foraging in the previous year at above 16\% of household income [65] (p. 184). Negative encounters are more frequent for villagers living closer to the park.

In a perspective focusing on conservation and social justice, PA and national parks as an outcome of exclusionary conservation policy create manifold problems for the communities in the vicinity, as in many other national contexts [66].

\section{Discussion}

From the literature hereto assessed, seven major narratives or causal explanations can be made out in the context of human-elephant conflict and elephant conservation in Sri Lanka. In other national and regional contexts, there might be more and different narratives than those identified here. For instance, officially sanctioned culling, albeit historically evident, is not relevant to current elephant management policy in Sri Lanka. Additionally, train and vehicle accidents are not further discussed since here human agency is seen as unintentional. 
The Sri Lankan government authorities, specifically the DWC, have focused their HEC mitigation efforts on deterrence, fencing, and dealing with problem elephants through translocation $[1,4,44,49,50]$. Our empirical data from field interviews in the dry zone [67] display the disconnect between the DWC's mitigation strategies and the subjective experiences of villagers affected by HEC. The inadequacy of the existing mitigation strategies has the potential to exacerbate HEC. Therefore, it is vital to assess the narratives guiding elephant conservation policy in Sri Lanka, and detect faulty or insufficient explanations of the problem.

Table 1 identifies the seven major causal explanations found in the literature. It must be noted that these are ideal types and that some of them are not mutually exclusive. In the following, we evaluate the merits and problems in each narrative.

Table 1. Major causal explanations for HEC in Sri Lanka. Source: Own compilation.

\begin{tabular}{|c|c|c|}
\hline Narrative & Main Causal Explanation & Examples in Literature \\
\hline Colonial legacy as historical cause & $\begin{array}{c}\text { Colonial hunting and land-use change in } \\
\text { British Ceylon led to elephant population } \\
\text { decrease and habitat loss }\end{array}$ & $\begin{array}{c}\text { Tennent (1860); Lorimer and Whatmore (2009); } \\
\text { Jayewardene }(1994 b)\end{array}$ \\
\hline Poaching & $\begin{array}{l}\text { Remote demand fuels criminal } \\
\text { poaching operations }\end{array}$ & Santiapillai et al. (1999) \\
\hline Population growth and habitat loss & $\begin{array}{l}\text { Human population growth drives } \\
\text { encroachment on elephant ranging grounds; } \\
\text { elephants and humans prove to } \\
\text { be incompatible }\end{array}$ & $\begin{array}{l}\text { Jayewardene (1994a); Santiapillai (1996); } \\
\text { Santiapillai and Wijeyamohan (2016) }\end{array}$ \\
\hline Crop raiding and socio-economic grievances & $\begin{array}{c}\text { Elephant crop raiding impacts household } \\
\text { economic security, leading to defensive } \\
\text { measures lethal to elephants }\end{array}$ & $\begin{array}{l}\text { Bandara and Tisdell (2002); Santiapillai et al. } \\
\text { (2010); Fernando (2000); Fernando et al. (2019) }\end{array}$ \\
\hline Problem elephants & $\begin{array}{c}\text { Male elephant individuals" problematic } \\
\text { behaviours primarily cause conflicts }\end{array}$ & $\begin{array}{l}\text { Haturusinghe and Weerakoon (2012); } \\
\text { Ekanayaka et al. (2011) }\end{array}$ \\
\hline Agricultural modernisation-failed cohabitation & $\begin{array}{c}\text { Changes in agricultural productions systems } \\
\text { or loss of traditional ecological knowledge } \\
\text { promote conflicts }\end{array}$ & $\begin{array}{c}\text { Anuradha et al. (2019); Lorimer (2010); } \\
\text { de Silva and Srinivasan (2019); } \\
\text { Ranaweerage (2012) }\end{array}$ \\
\hline (Neoliberal) conservation and social justice & $\begin{array}{l}\text { Rigid conservation practices in protected areas, } \\
\text { designed to attract tourists, disenfranchise } \\
\text { local people and facilitate escalating conflicts }\end{array}$ & Benadusi (2015); de Silva and Srinivasan (2019) \\
\hline
\end{tabular}

The colonial legacy is not as evident as other narratives, but it resurfaces in accounts on conservation of the threatened Sri Lankan elephant. Indeed, colonial-era land-use decisions have determined the modern extents of the elephant ranges in Sri Lanka. The British colonial power promoted the transformation of large swathes of Sri Lankan highlands into plantations, first mostly for coffee, later for tea [68]. This large-scale conversion of forest into cultivated land inevitably led to the elephant population's displacement from the wet zone. In the past, the main habitat of Sri Lankan elephants was the mountainous region of the uphill country, for example, in the Horton Plains. This was due to the abundance of soft grasses easily digested by elephants in the humid environment and the abundance of water in this region. However, coffee cultivation, and later tea plantations in those areas led to the displacement of elephants to the dry zone. Hence, in addition to hunting, as discussed above, the colonial plantation economy had a substantial impact on the Sri Lankan elephant population. Jayewardene [69], quoted in Lorimer and Whatmore [27], estimates that 17,000 Sri Lankan elephants were killed, exported or died in captivity during the 19th century. However, the historical legacy of colonialism does not explain the recent escalation of HEC throughout Sri Lanka in the 21st century.

Poaching cannot be weighted as a major element of human-elephant conflict in Sri Lanka. The historical political economy and commodity chains that drove poaching in Sri Lanka at the time of the civil war [35] have dried up. However, new findings [39] have highlighted the increase in illegal captures and the live elephant trade, which has the potential to create problems for elephant conservation. Still, poaching does not appear to be a main concern in the Sri Lankan context. 
On the other hand, habitat fragmentation continues to be seen as a major underlying cause of HEC in Sri Lanka. The proscribed mitigation mechanism for habitat loss is, quite obviously, the establishment or expansion of PA. This is the historically dominant "mainstream conservation" approach [70]. It is based mainly on the position that human beings and nature cannot live harmoniously side-by-side. Therefore, PA must be set up to protect nature (and especially endangered species) from the destructive influence of humans. Within biodiversity conservation, there is a vivid debate on land sharing, the less intensive, more wildlife-friendly resource use of land resources, and land sparing, which results in the creation and expansion of protected areas without significant human interference for biodiversity conservation [71,72]. In the dominant version, this narrative is frequently linked to human population growth. Yet, political ecologists have been known to question a specific link between human population growth and environmental degradation, a theoretical assumption they call neo-Malthusian [73] (pp. 14-18).

In Sri Lanka, habitat loss and habitat fragmentation are not a simple functions of population growth. Above $80 \%$ of the land surface is under state ownership, which emphasises the primacy of the state in land-use change decisions and conservation policy [74]. The following example may illustrate this: The Mahaweli Development Program (MDP), a massive irrigation and resettlement program in the dry zone [75], transformed large land areas for agricultural cultivation. It has been pursued by different governments since independence but accelerated in the late 1970s and 1980s under the executive presidency of J.R. Jayewardene [76]. The construction of new settlements in the Mahaweli river basin led to elephant habitat fragmentation, creating a mosaic of foresty and human-dominated landscape and, mid-term, considerable HEC in the region [53]. The example underlines that habitat fragmentation is the outcome of political processes of economic development and planning. Therefore, a conflation of habitat loss with human and/or elephant population growth is a neo-Malthusian fallacy, as habitat loss and fragmentation result from complex historical development processes. Moreover, Kumar et al. [77] argue that the shared landscapes inhabited by humans and elephants are already a result of elephants' adaptation to habitat loss, as elephants are generalists able to survive in different habitats. Existing studies on land-use change in Sri Lankan forests are inconclusive and show diverging results: in some areas, forest cover has actually increased due to out-migration and conflict-related decrease in agricultural activities [78,79]. The role of the encroachment of farming communities on forests and, consequently, its impact on HEC is one that deserves more scrutiny.

Crop raids are widely seen as the root causes of human-elephant conflict. No less than 14,516 incidents of HEC in Sri Lanka were reported to the DWC in the period 2010-2019 [80]. More than half of the farmers with elephants in their vicinity report negative encounters [2]. Santiapillai et al. [45] found that the vast majority (89\%) of interviewed farming families earned less than Rs 120,000 per year, indicating that financial strain from elephant-related crop losses is serious; however, their findings are more than ten years old and rely on a relatively small sample. While socio-economic grievances resulting from elephant crop foraging are indeed a powerful driver of HEC [43], the impacts of such incidents on rural development and the trajectories of HEC under conditions of socio-economic vulnerability are under-researched in the Sri Lankan contexts. Even though the economic impacts of elephant crop-raids on small-scale farming households and communities need to be incorporated in any explanation of HEC, social conditions may vary widely at the local level. What the narrative in its current form leaves open is the question of adequate mitigation strategies. Although compensation payments promise to be a necessary element of a sustainable HEC mitigation strategy, implementation on the ground appears to be deeply flawed, as almost no compensation for crop depredation is handed out $[45,67]$.

The notion of "problem elephants" is based on the assumption that the behaviour of individual elephants (mostly bulls) is responsible for most hostile encounters between elephants and humans. Male individuals, especially in musth (a hormonal condition), have been shown to cause the most frequent damage $[1,4,53]$ and to be extremely dangerous to 
humans. Their behavioural biology must be taken into account when considering HEC mitigation strategies. However, it appears doubtful that removing (i.e., translocating) these individuals from affected landscapes is an efficient way to mitigate the problem. As was shown above, translocation is now seen as an ineffectual and rather costly method of human-elephant conflict mitigation. Altogether, translocation appears to be an inept mitigation mechanism, although it is potentially politically viable because it shows the responsible authorities "doing something". There are other reasons why the "problem elephants" narrative is problematic in itself. While single bulls and small groups of bulls appear to be much more frequently engaged in crop-raiding, female-led herds may also partake [32] (pp. 116-119) and may even cause more damage than single bulls [81] (p. 10). Additionally, this narrative ignores long-term social-ecological dynamics, favouring a narrow emphasis on individual animal behaviour and cannot address HEC's multidimensional aspects.

The "failed cohabitation-agricultural modernisation" narrative is based on a relatively complex and coherent historical argument. It indicates that the decline of chena cultivation, the shift to a more intensive, "modern" form of agriculture, the loss of traditional ecological knowledge, and the increase in HEC are intertwined and long-term historical processes. This position is influenced by the post-humanist turn in geography, which stresses the interlinkage of multispecies assemblages, henceforth the agency of non-human creatures. The broad approach has been variously labelled as animal geographies [82-85], posthumanist geographies [86] or multinatural geographies [87]. This approach is marked by the attempt to overcome human-nature dichotomies, calling for a new ethics of harmonious coexistence by questioning the hierarchical anthropocentric order [88]. Lorimer [62] strives to explore the chances of conviviality between humans and elephants and describes Sri Lankan elephants as "companion species", less-than-wild animals that live in spaces profoundly shaped by human activities. Other contributions [65,85] emphasise the history of (relatively) peaceful cohabitation in the traditional chena landscapes of the Sri Lankan dry zone.

A systemic critique of the sustainability of the current agricultural production model in Sri Lanka is valid and supported by sound evidence from microlevel case studies. However, the position that modernised agriculture is the main reason for a breakdown of peaceful cohabitation of species is in danger of falling for the idea of a nostalgic past. Elephants and humans have come into conflict already in the past, i.e., before the modernisation of agriculture [21,24], although not to the current extent. A return to chena cultivation cannot be proscribed as a panacea. Still, there is an urgent need to reconsider the sustainability of Sri Lankan agri-ecological systems, also concerning HWC.

Political ecologies of elephant conservation in Sri Lanka [64,65] criticise the commodification of the "nature experience" in international tourism and the enclosure of commons under the guise of conservation. Political ecology as a critical theory of nature-society relations is at the root of a reflective critique of traditional—often (post-) colonial—conservation policies. Lately, it has focused on a critique of "neoliberal conservation" [89-91] as the most prevalent regime governing biodiversity conservation practices. However, it must be understood that national parks and other PAs are not only, and maybe not primarily, "cash cows" for neoliberal ecotourism, but also nationalist projects that embody ideological concepts of heritage, nature, and nation [92]. Additionally, the "neoliberal conservation" narrative connected to a political ecology critique here only provides partially explanatory power, as most human-elephant encounters happen outside of PA and are not the direct result of PA design. While a critique of conservation policies regarding PA is legitimate, it misses the point with regard to a majority of the hostile encounters in HEC.

\section{Conclusions}

This paper reviews causal explanations of human-elephant conflict in Sri Lanka by identifying the underlying narratives resurfacing in the accounts of these positions. It is important to trace the core assumptions for these causal explanations since they are 
most likely to inform decision-makers and wildlife authorities to design interventions. While undertaking this analysis, the different narratives in causal explanations are assessed regarding their empirical content; some, such as the popular population growth-habitat loss argument, and the conservation and social justice narrative, appear to be too onedimensional to unfold explanatory power.

What is more, this review detects a gap in the literature on HEC in Sri Lanka. Socioeconomic vulnerability and its effect on human hostility towards elephants are poorly understood, despite some promising advances in the field $[93,94]$. Sri Lanka is a lowermiddle-income country with a comparatively well-established welfare system [95], and the Global Food Security Index [96] ranks Sri Lanka as 66th of 113. This being said, pockets of severe poverty exist in the country, especially in rural areas. There is no clear evidence if HEC might altogether be a substantial/widespread threat to household food security in the sense that affected households are in danger of acute undernutrition due to crop raids. However, villagers' socio-economic and psychosocial consequences when frequently afflicted by elephant raids are stark [81]. More research is needed to evaluate the traumatic components of HEC on vulnerable communities to design effective and inclusive mitigation measures to human-elephant conflict in the country with the highest elephant-to-human-population ratio.

Altogether, the existing narratives lack a holistic understanding of HEC as a complex social-ecological problem; the narratives emphasise ecological causes rooted in animal behaviour and habitat loss or the political-economic dimensions of agrarian change and conservation policy. Complex ecological interactions are underexplored, e.g., the influence of recurring droughts and floods in the country on food scarcity and the frequency of crop foraging; the feedback mechanism of elephant killings on herd structure and raiding behaviour; and the exact impact of human land-use decisions regarding crop selection and farm size. There is a need to understand social-ecological feedbacks and institutional conditions that enable and constrain HEC in rural Sri Lanka. There is an emergent understanding that HEC in Sri Lanka is driven by complex interactions between different economic, social, political and environmental factors. These factors ought to be integrated into a single theoretical framework.

Author Contributions: Conceptualisation, S.K., S.S.W. and R.P.; methodology, S.K., S.S.W. and C.S.; writing-original draft preparation, S.K.; writing-review and editing, S.K., S.S.W., R.P., C.R.W., D.U.G., T.S.N., C.C.W., B.M.N., N.N.R., C.D.S. and C.S.; supervision-C.R.W., C.S. and A.T.; funding acquisition and project administration-S.K. All authors have read and agreed to the published version of the manuscript.

Funding: This review is partially supported through a grant by the Zentrale Forschungsförderung (ZFF, central research fund) of the University of Kassel, Germany, for the project "Human-elephant conflict in Sri Lanka" (2019-2020).

Data Availability Statement: Not applicable.

Conflicts of Interest: The authors declare no conflict of interest.

\section{References}

1. Fernando, P. Managing elephants in Sri Lanka: Where we are and where we need to be. Ceylon J. Sci. Biol. Sci. 2015, 44. [CrossRef]

2. Fernando, P.; De Silva, M.C.R.; Jayasinghe, L.; Janaka, H.; Pastorini, J. First country-wide survey of the Endangered Asian elephant: Towards better conservation and management in Sri Lanka. Oryx 2019, 55, 46-55. [CrossRef]

3. Thenakoon, T.M.S.P.K.; Thisara Kandambige, L.S.; Liyanage, C. Impact of human-elephant conflict on livelihood: A case study from a rural setting of Sri Lanka. Int. J. Appl. Res. 2017, 3, 1107-1111.

4. Fernando, P.; Jayewardene, J.; Prasad, T.; Hendavitharana, W.; Pastorini, J. Current status of Asian Elephants in Sri Lanka. Gajah 2011, 35, 93-103. [CrossRef]

5. Trautman, T.R. Elephants and Kings. An Environmental History; University of Chicago Press: Chicago, IL, USA, 2015.

6. Chögyel, T. The Life of the Buddha; Penguin: London, UK, 2015.

7. Courchamp, F.; Jaric, I.; Albert, C.; Meinard, Y.; Ripple, W.J.; Chapron, G. The paradoxical extinction of the most charismatic animals. PLoS Biol. 2018, 16, e2003997. [CrossRef] [PubMed] 
8. Perera, B.M.A.O. The human-elephant conflict: A review of current status and mitigation methods. Gajah 2009, 30, 41-52. [CrossRef]

9. Menon, V.; Tiwari, S.K. Population status of Asian elephants Elephas maximus and key threats. Int. Zoo Yearboook 2019, 53, 17-30. [CrossRef]

10. Mithen, S. The Hunter-Gatherer Prehistory of Human-Animal Interactions. Anthrozoös 1999, 12, 195-204. [CrossRef]

11. Broughton, J.M.; Weitzel, E.M. Population reconstructions for humans and megafauna suggest mixed causes for North American Pleistocene extinctions. Nat. Commun. 2018, 9, 1-12. [CrossRef]

12. Nogues-Bravo, D.; Rodriguez, J.; Hortal, J.; Batra, P.; Araújo, M.B. Climate Change, Humans, and the Extinction of the Woolly Mammoth. PLoS Biol. 2008, 6, e79. [CrossRef]

13. Treves, A.; Santiago-Ávila, F.J. Myths and assumptions about human-wildlife conflict and coexistence. Conserv. Biol. 2020, 34, 811-818. [CrossRef] [PubMed]

14. Nyhus, P.J. Human-Wildlife Conflict and Coexistence. Annu. Rev. Environ. Resour. 2016, 41, 143-171. [CrossRef]

15. Peterson, M.; Birckhead, J.; Leong, K.; Peterson, M.; Peterson, T.R. Rearticulating the myth of human-wildlife conflict. Conserv. Lett. 2010, 3, 74-82. [CrossRef]

16. Redpath, S.; Bhatia, S.; Young, J. Tilting at wildlife: Reconsidering human-wildlife conflict. Oryx 2014, 49, 222-225. [CrossRef]

17. Baynham-Herd, Z.; Redpath, S.; Bunnefeld, N.; Molony, T.; Keane, A. Conservation conflicts: Behavioural threats, frames, and intervention recommendations. Biol. Conserv. 2018, 222, 180-188. [CrossRef]

18. Aukes, E.J.; Bontje, L.E.; Slinger, J.H. Narrative and frame analysis: Disentangling and refining two close relatives by means of a large infrastructural technology case. Forum Qual. Soc. Res. 2020, 21, 28. [CrossRef]

19. Geiger, W. (Ed.) Mahavamsa; Asian Educational Services: New Delhi, India, 1996.

20. Paranavitana, S. The Triumph of Duttagamini; Ceylon University Press: Peradeniya, Sri Lanka, 1959; Volume 1, pp. 145-163.

21. Santiapillai, C.; Wijeyamohan, S. Conservation and the History of Human-Elephant Relations in Sri Lanka. In Conflict, Negotiation, and Coexistence. Rethinking Human-Elephant Relations in South Asia; Locke, P., Buckingham, J., Eds.; Oxford University Press: New Delhi, India, 2016; pp. 229-241. [CrossRef]

22. De Silva, K.M. A History of Sri Lanka; Vijitha Yapa Publications: Colombo, Sri Lanka, 2005.

23. Olivier, R. Distribution and Status of the Asian Elephant. Oryx 1978, 14, 379. [CrossRef]

24. Fernando, P. Elephants in Sri Lanka: Past, present and future. Loris 2000, 22, 28-44.

25. Santiapillai, C. The Difficulty in Estimating the Total Population Size of Wild Elephants in Sri Lanka. Ceylon J. Sci. Biol. Sci. 2014, 42, 101. [CrossRef]

26. De Butts, A. Rambles in Ceylon; W.H. Allen and Co.: London, UK, 1841.

27. Lorimer, J.; Whatmore, S. After the 'king of beasts': Samuel Baker and the embodied historical geographies of elephant hunting in mid-nineteenth-century Ceylon. J. Hist. Geogr. 2009, 35, 668-689. [CrossRef]

28. Tennent, J.E. Ceylon: An Account of the Island. Physical, Historical and Topographical, 4th ed.; Longman, Green, Longman and Roberts: London, UK, 1860; Volume 2.

29. Grove, R. Green Imperialism. Colonial Expansion, Tropical Island Edens and the Origins of Environmentalism, 1600-1860; Cambridge University Press: Cambridge, UK, 1995.

30. Jayewardene, J. The care and management of domesticated Asian elephants in Sri Lanka. In Giants in Our Hands, Proceedings of the International Workshop on the Domesticated Asian Elephant; Baker, I., Kashio, M., Eds.; FAO Regional Office for Asia and the Pacific: Bangkok, Thailand, 2002; pp. 43-45.

31. Bandara, R.; Tisdell, C. Conserving Asian Elephants: Economic Issues Illustrated by Sri Lankan Concerns; University of Queensland: Brisbane, Australia, 2001.

32. Sukumar, R. The Asian Elephant: Ecology and Management; Cambridge University Press: Cambridge, UK; New York, NY, USA, 1989.

33. Kurt, F.; Hartl, G.B.; Tiedemann, R. Tuskless bulls in Asian elephant Elephas maximus. History and population genetics of a man-made phenomenon. Acta Thériol. 1995, 40, 125-143. [CrossRef]

34. Chaiklin, M. Ivory in Early Modern Ceylon: A Case Study in What Documents Don't Reveal. Int. J. Asian Stud. 2009, 6, 37-63. [CrossRef]

35. Santiapillai, C.; Silva, A.; Karyawasam, C.; Esufali, S.; Jayaniththi, S.; Basnayake, M.; Unantenne, V.; Wijeyamohan, S. Trade in Asian elephant ivory in Sri Lanka. Short Communications. Oryx 1999, 33, 176-180. [CrossRef]

36. Duffy, R. Nature Crime. How We're Getting Conservation Wrong; Yale University Press: London, UK; New Haven, CT, USA, 2010.

37. Aryal, A.; Morley, C.; McLean, I.G. Conserving elephants depend on a total ban of ivory trade globally. Biodivers. Conserv. 2018, 27, 2767-2775. [CrossRef]

38. Neme, L. One Country will Destroy Its Ivory_And Pray for Elephants. 2016. Available online: https://www.nationalgeographic com/news/2016/01/160125-sri-lanka-elephants-buddhism-ivory-stockpile-cites/ (accessed on 14 March 2020).

39. Prakash, T.G.S.L.; Indrajith, W.A.A.D.U.; Aththanayaka, A.M.C.P.; Karunarathna, S.; Botejue, M.; Nijman, V.; Henkanaththegedara, S. Illegal capture and internal trade of wild Asian elephants (Elephas maximus) in Sri Lanka. Nat. Conserv. 2020, 42, 51-69. [CrossRef]

40. Department of Census and Statistics. The Population of Sri Lanka; Department of Census and Statistics: Colombo, Sri Lanka, 1974. 
41. Department of Census and Statistics. Census of Population and Housing 2012; Department of Census and Statistics: Colombo, Sri Lanka, 2015.

42. Jayewardene, J. Elephant drives in Sri Lanka. Gajah 1994, 13, 30-39.

43. Bandara, R.; Tisdell, C. Asian Elephants as Agricultural Pests: Damages, Economics of Control and Compensation in Sri Lanka; University of Queensland: Brisbane, Australia, 2002; p. 65.

44. Santiapillai, C. Mitigation of human-elephant conflicts in Sri Lanka. Gajah 1996, 15, 1-6.

45. Santiapillai, C.; Wijeyamohan, S.; Bandara, G.; Athurupana, R.; Dissanayake, N.; Read, B.; Dissanayake, D.M.N.J. An assessment of the human-elephant conflict in Sri Lanka. Ceylon J. Sci. Biol. Sci. 2010, 39, 21. [CrossRef]

46. Ekanayaka, S.K.K.; Campos-Arceiz, A.; Rupasinghe, M.; Pastorini, J.; Fernando, P. Patterns of crop raiding by Asian elephants in a human-dominated landscape in Southeastern Sri Lanka. Gajah 2011, 34, 20-25. [CrossRef]

47. Tudge, C. Asia's elephants: No place to hide-African elephants are being killed for their ivory. But their Asian cousins are being threatened just as surely by subtler forces. New Sci. 1994, 141, 34-37.

48. Haturusinghe, H.S.; Weerakoon, D.K. Crop raiding behaviour of elephants in the Northwestern Region of Sri Lanka. Gajah 2012, 36, 26-31.

49. DWC. Department of Wildlife Conservation Performance Report 2018; Report 90; DWC: Battaramulla, Sri Lanka, 2019.

50. DWC. Department of Wildlife Conservation Performance Report 2017; Report 87; DWC: Battaramulla, Sri Lanka, 2018.

51. De Silva, S.; Webber, C.E.; Weerathunga, U.S.; Pushpakumara, T.V.; Weerakoon, D.K.; Wittemyer, G. Demographic Variables for Wild Asian Elephants Using Longitudinal Observations. PLoS ONE 2013, 8, e82788. [CrossRef] [PubMed]

52. DWC. Department of Wildlife Conservation Performance Report 2012; DWC: Battaramulla, Sri Lanka, 2013; p. 225.

53. Fernando, P.; Leimgruber, P.; Prasad, T.; Pastorini, J. Problem-Elephant Translocation: Translocating the Problem and the Elephant? PLoS ONE 2012, 7, e50917. [CrossRef]

54. Fernando, P.; Wikramanayake, E.; Weerakoon, D.; Jayasinghe, L.; Gunawardene, M.; Janaka, H. Perceptions and Patterns of Human-Elephant Conflict in Old and New Settlements in Sri Lanka: Insights for Mitigation and Management. Biodivers. Conserv. 2005, 14, 2465-2481. [CrossRef]

55. National Audit Office. Performance of the Horowpothana Elephant Holding Ground; Report No: IEN/F/DWC/19/PR/11; National Audit Office: Baththaramulla, Sri Lanka, 2019; p. 50.

56. De Alwis, S. Experiments with Elephants: How Sustainable are Elephant-Holding Grounds? 2020. Available online: http:/ www. dailymirror.lk/news-features / Experiments-with-elephants-How-sustainable-are-elephant-holding-grounds /131-181293 (accessed on 14 March 2020).

57. Mendis, R. The Problem with Problem Elephants. 2019. Available online: https://ceylontoday.lk/features-more/3613 (accessed on 14 March 2020).

58. Anuradha, J.M.P.N.; Fujimura, M.; Inaoka, T.; Sakai, N. The Role of Agricultural Land Use Pattern Dynamics on Elephant Habitat Depletion and Human-Elephant Conflict in Sri Lanka. Sustainability 2019, 11, 2818. [CrossRef]

59. Ranaweerage, E. Agricultural lifestyle, perspectives and conservational issues in protected areas: A study of human-elephant conflict in Pidurangala in the Central Province of Sri Lanka. Geogr. Rev. Jpn. Ser. B 2012, 85, 17-28. [CrossRef]

60. Pastorini, J.; Nishantha, H.G.; Janaka, H.K.; Isler, K.; Fernando, P. Water-Body Use by Asian elephants in Southern Sri Lanka. Trop. Conserv. Sci. 2010, 3, 412-422. [CrossRef]

61. Gunatilleke, N.; Pethiyagoda, R.; Gunatilleke, S. Biodiversity of Sri Lanka. J. Nat. Sci. Found Sri Lanka 2008, 36, 25-62. [CrossRef]

62. Lorimer, J. Elephants as companion species: The lively biogeographies of Asian elephant conservation in Sri Lanka. Trans. Inst. Br. Geogr. 2010, 35, 491-506. [CrossRef]

63. Sriyananda, S. Sri Lanka's Wildlife Conservation Disrupted by Political Influences Say Conservationists. 2019. Available online: http:/ / www.ft.lk/opinion/Sri-Lanka-s-Wildlife-Conservation-Disrupted-by-Political-Influences-Say-Conservationists / 14-680215 (accessed on 14 March 2020).

64. Benadusi, M. Elephants Never Forget: Capturing Nature at the Border of Ruhuna National Park (Yala), Sri Lanka. Capital. Nat. Soc. 2014, 26, 77-96. [CrossRef]

65. De Silva, S.; Srinivasan, K. Revisiting social natures: People-elephant conflict and coexistence in Sri Lanka. Geoforum 2019, 102, 182-190. [CrossRef]

66. Brockington, D. Fortress Conservation: The Preservation of the Mkomazi Game Reserve, Tanzania; International African Institute: Oxford, UK, 2002.

67. Köpke, S.; Withanachchi, S.S.; Pathiranage, R.; Withanachchi, C.R.; Udayakanthi, T.G.D.; Nissanka, N.M.T.S.; Warapitiya, C.; Nissanka, L.N.A.B.M.; Rana-singhe, R.A.N.N.; Senarathna, T.M.C.D.; et al. Political ecology of human-elephant conflict in the Sri Lankan dry zone. Unpublished Manuscript.

68. Webb, J.L.A. Tropical Pioneers: Human Agency and Ecological Change in the Highlands of Sri Lanka, 1800-1900; Ohio University Press: Athens, OH, USA, 2002.

69. Jayewardene, J. The Elephant in Sri Lanka; Wildlife Heritage Trust of Sri Lanka: Colombo, Sri Lanka, 1994.

70. Brockington, D.; Duffy, R.; Igoe, J. Nature Unbound: Conservation, Capitalism and the Future of Protected Areas; Routledge/Earthscan: London, UK; New York, NY, USA, 2008.

71. Fischer, J.; Batary, P.; Bawa, K.S.; Brussaard, L.; Chappell, M.J.; Clough, Y.; Daily, G.C.; Dorrough, J.; Hartel, T.; Jackson, L.E.; et al. Conservation: Limits of Land Sparing. Science 2011, 334, 593. [CrossRef] 
72. Tscharntke, T.; Clough, Y.; Wanger, T.C.; Jackson, L.; Motzke, I.; Perfecto, I.; Vandermeer, J.; Whitbread, A. Global food security, biodiversity conservation and the future of agricultural intensification. Biol. Conserv. 2012, 151, 53-59. [CrossRef]

73. Robbins, P. Political Ecology: A Critical Introduction, 3rd ed.; Wiley-Blackwell: Malden, MA, USA; Oxford, UK, 2019.

74. Mapa, R.B.; Kumuragame, D.; Gunarathne, W.D.I.; Dassanayake, A.R. Land use in Sri Lanka; past, presents and the future. In Proceedings of the 17th World Congress of Soil Scientist (WCSS 2002), Bangkok, Thailand, 14-21 August 2002.

75. Withanachchi, S.S.; Köpke, S.; Withanachchi, C.R.; Pathiranage, R.; Ploeger, A. Water Resource Management in Dry Zonal Paddy Cultivation in Mahaweli River Basin, Sri Lanka: An Analysis of Spatial and Temporal Climate Change Impacts and Traditional Knowledge. Climate 2014, 2, 329-354. [CrossRef]

76. Zubair, L. Modernisation of Sri Lanka's Traditional Irrigation Systems and Sustainability. Sci. Technol. Soc. 2005, 10, 161-195. [CrossRef]

77. Kumar, M.A.; Vijayakrishnan, S.; Singh, M. Whose Habitat Is It Anyway? Role of Natural and Anthropogenic Habitats in Conservation of Charismatic Species. Trop. Conserv. Sci. 2018, 11. [CrossRef]

78. Lindström, S.; Mattsson, E.; Nissanka, S. Forest cover change in Sri Lanka: The role of small scale farmers. Appl. Geogr. 2012, 34, 680-692. [CrossRef]

79. Suthakar, K.; Bui, E.N. Land use/cover changes in the war-ravaged Jaffna Peninsula, Sri Lanka, 1984-early 2004. Singap. J. Trop. Geogr. 2008, 29, 205-220. [CrossRef]

80. Prakash, T.G.S.L.; Wijeratne, A.L.; Fernando, P. Human-elephant conflict in Sri Lanka: Patterns and extent. Gajah 2020, 51, 16-25.

81. Desai, A.A.; Riddle, H.R. Human-Elephant Conflict in Asia; U.S. Fish and Wildlife Service; Asian Elephant Support: Washington, DC, USA, 2016; p. 92.

82. Emel, J.; Wilbert, C.; Wolch, J. Animal geographies. Soc. Anim. 2002, 10, 407-412. [CrossRef]

83. Gillespie, K.; Collard, R.-C. (Eds.) Critical Animal Geographies: Politics, Intersections and Hierarchies in a Multispecies World; Routledge: London, UK; New York, NY, USA, 2015.

84. Hovorka, A.J. Animal geographies III: Species relations of power. Prog. Hum. Geogr. 2018, 43, 749-757. [CrossRef]

85. Lorimer, J.; Srinivasan, K. Animal Geographies. In The Wiley-Blackwell Companion to Cultural Geography, 1st ed.; Johnson, N.C., Schein, R.H., Winders, J., Eds.; Wiley-Blackwell: Hoboken, NJ, USA, 2013.

86. Margulies, J.; Bersaglio, B. Furthering post-human political ecologies. Geoforum 2018, 94, 103-106. [CrossRef]

87. Lorimer, J. Wildlife in the Anthropocene: Conservation after Nature; University of Minnesota Press: Minneapolis, MN, USA, 2015.

88. Kopnina, H. Wild Animals and Justice: The Case of the Dead Elephant in the Room. J. Int. Wildl. Law Policy 2016, 19, 219-235. [CrossRef]

89. Igoe, J.; Brockington, D. Neoliberal conservation: A brief introduction. Conserv. Soc. 2007, 5, 432-449.

90. Büscher, B.; Sullivan, S.; Neves, K.; Igoe, J.; Brockington, D. Towards a Synthesized Critique of Neoliberal Biodiversity Conservation. Cap. Nat. Soc. 2012, 23, 4-30. [CrossRef]

91. Büscher, B.; Dressler, W.; Fletcher, R. (Eds.) Nature Inc.: Environmental Conservation in the Neoliberal Age; The University of Arizona Press: Tucson, AZ, USA, 2014.

92. Jazeel, T. 'Nature', nationhood and the poetics of meaning in Ruhuna (Yala) National Park, Sri Lanka. Cult. Geogr. 2005, 12, 199-227. [CrossRef]

93. Van De Water, A.; Matteson, K. Human-elephant conflict in western Thailand: Socio-economic drivers and potential mitigation strategies. PLoS ONE 2018, 13, e0194736. [CrossRef]

94. Compaore, A.; Sirima, D.; Hema, E.M.; Doamba, B.; Ajong, S.N.; Di Vittorio, M.; Luiselli, L. Correlation between increased human-elephant conflict and poaching of elephants in Burkina Faso (West Africa). Eur. J. Wildl. Res. 2020, 66, 24. [CrossRef]

95. Newhouse, D.L.; Becerra, P.S.; Doan, D. Sri Lanka Poverty and Welfare: Recent Progress and Remaining Challenges; World Bank: Washington, DC, USA, 2016. [CrossRef]

96. Global Food Security Index. Global Food Security Index 2019; EIU/Corteva: Wilmington, DE, USA, 2019 ; p. 48. 